\title{
Calculation of bottom sediment discharge in trapezoidal channels
}

\author{
Shakhboz Latipov ${ }^{1 *}$, Isroil Gayimnazarov ${ }^{1}$, Sobir Eshev ${ }^{1}$, Iroda Babajanova $^{2}$, Yuldash \\ Babajanov $^{3}$, and Bobur Shodiev ${ }^{4}$ \\ ${ }^{1}$ Karshi engineering- economics institute, Karshi, Uzbekistan \\ ${ }^{2}$ The Higher Military Aviation School the Republic of Uzbekistan, Karshi, Uzbekistan \\ ${ }^{3}$ Karshi State University, Karshi, Uzbekistan \\ ${ }^{4}$ Tashkent institute of irrigation and agricultural mechanization engineers, Tashkent, Uzbekistan
}

\begin{abstract}
The article shows the advantages of the Van-Rijn method from the analysis of existing calculation methods for determining the sediment discharge. Based on the results of laboratory studies and the Van-Rijn dependence, dependence was obtained to determine the discharge of bottom sediment, taking into account the establishment of the channel slopes. The resulting dependence is compared with the dependences obtained by other researchers, and these comparisons show good convergence between them.
\end{abstract}

\section{Introduction}

In determining the movement of underground aquifers, the following approaches are used: deterministic, probability and rifle movement of aquifers[1-8], [17-21].

In the deterministic approach, the action of a single-sex large-section particle at the bottom of a flat stream is considered in the mode of square resistances. It is accepted to strain the bottom of the tub, as there will be a basis providing the extraction of discharges from the bottom of the Uzan. This parameter is entered either directly in the computational formulas $_{u_{*}}=\sqrt{T_{0} / \rho_{v}}$, or through the size of the flow dynamic speed. As a quantitative indicator of the driving force, the difference $\left(u_{0}-u_{n}\right)$ in the values of this voltage at the beginning of the underground impulse voltage and particle motion is assumed. In some cases, the difference in impulse voltages is replaced by the difference in the vertical by the middle and non-washable speeds of the current $\left(u_{0} / \sqrt{g d_{a v}}\right)$. The differences, in this case, represent the speed of the subterranean particles, and the magnitude represents the number of particles participating in the movement. The difference or ratio of the dynamic speed and its critical speed is considered in other cases [18-26].

It is also one of the methods of calculation of underground ores. It is a method of determining the number of ores transported from the bottom to the bottom of the channel, which is in the form of an underground wavy motion. The movement of the underground formation that occurs in this situation is considered to be smoothly variable; that is, all the

\footnotetext{
*Corresponding author: shakhboz2016@mail.ru
} 
static characteristics of the underground release, particularly its average height and the average length of its rifle, will not depend on the time.

Having considered the movement of the underground wave as flat, we write the complete differential of the height of the desired point of the underground line in one moment $[3,4]$ :

$$
\partial z_{0}=\frac{\partial z_{0}}{\partial x} d x+\frac{\partial z_{0}}{\partial t} d t
$$

You will be able to determine the height and move along the bottom of the bottom on $d z_{0}$ this point:

$$
\frac{\partial z_{0}}{\partial x} \frac{d x}{d t}+\frac{\partial z_{0}}{\partial t}=0
$$

$Z_{0}$ from the differential equation of deformation, which is written for a point, we get the following:

$$
\left(\frac{\partial z_{0}}{\partial t}\right)=-(1-\varepsilon)\left(\frac{\partial q_{b o t}}{\partial x}\right) z_{0}
$$

where $\varepsilon$ is the grount porosity coefficient.

By putting (3) to (2) and saying the speed of point movement, we will have the following:

$$
\left(\frac{\partial q_{b o t}}{\partial x}\right)=(1-\varepsilon) C_{z_{0}} \frac{\partial z_{0}}{\partial x}
$$

By integrating (4), we will have the following:

$$
q_{b o t}=(1-\varepsilon) C_{z_{0}} Z_{0} F(t)
$$

$F(t)=0, C_{z_{0}}=C_{g r}=$ const we take that and form the following:

$$
q_{b o t}=(1-\varepsilon) C_{g r} Z_{0}
$$

(6) by integrating the equation, we will have an equation that will determine the average consumption of ores by the length of:

$$
q_{b o t}=(1-\varepsilon) C_{g r} Z_{0}
$$

Here $C_{g r}, h_{g r}$, are the speed and height of the movement of the ridges $\sigma=\omega_{g r} / h_{g r} h_{g r}$, respectively; -the coefficient taking into account the completeness of the wave profile. 
It is accepted that in most cases $(1-\varepsilon) \sigma \approx 0.5$ Taking this into account, we write (6) in the following form:

$$
q_{b o t}=0.5 \rho_{n} C_{g r} h_{g r}
$$

So, when calculating the comparative cost of underground grays, it will be necessary to determine the height of underground grays and their speed of movement.

The existing computational methods for determining Underground Discharge were recommended based on the experimental data of several researchers. Based on the analysis of these methods, Van-Rijn [3] method was seen to have a slight advantage over other proposed [6-16] methods. For this reason, the same method was chosen in improving the calculation method of tubular discharge in large graded channels [27-32]. According to this method, underground ores act as vibrations and oscillations on the underground surface. The comparative consumption of underground discharges is determined by the following equation.

$$
q_{b o t}=u_{b} C_{b} \delta_{g}
$$

here $u_{b}$ is the speed of the particles of the underground whitish; $\delta_{g}$ is saltation moving height; $C_{b}$ isthe volumetric concentration of the particle.

$u_{b} C_{b} \delta_{g}$ is expression for discrete particles above the flat bottom, which show the force of balance, which affects the moving particle, are divided by having based on the finite solution of the equation of motion: the forces of resistance and weight, the acceleration and lifting forces of the particle. The link obtained as a result of the finite solution is brought to the following view:

$$
\left\{u_{b} C_{b} \delta_{g}\right\}=f c t\left\{D_{*} T\right\}
$$

The main basis of the method of it is reflected in the following views:

$$
\begin{aligned}
& D_{*}=d_{a v}\left[\frac{(S-1) g}{v^{2}}\right]^{1 / 3} \\
& T=\frac{\left(u_{*}^{\prime}\right)^{2}-\left(u_{*_{\mathrm{cr}}}^{\prime}\right)^{2}}{\left(u_{* \mathrm{cr}}^{\prime}\right)^{2}}
\end{aligned}
$$

here $\boldsymbol{v}_{\text {is }}$ the coefficient of fluid kinematic curvature; $\boldsymbol{u}_{*}^{\prime}$-incoherent dynamic roughness velocity; $u_{* \text { cr }}^{\prime}$ is dynamic speed of the beginning of the movement of flux, which is determined from the curve of Schields [5]. 
Schields [5] to facilitate the detection of the dynamic speed of the start of the movement of tubular discharges. Summarizes its proposed curve graph with the following image:

$$
\left(u_{*}^{\prime}\right)^{2}=\theta_{c r}(S-1) g d_{a v}
$$

here $\theta$-.The Schields parameter is defined as follows:

$$
\begin{aligned}
& D_{*} \leq 4 \text { when } \theta_{c r}=0.24\left(D_{*}\right)^{-1} \\
& 4<D_{*} \leq 10 \text { when } \theta_{c r}=0.14\left(D_{*_{i}}\right)^{-0,66} \\
& 10<D_{*} \leq 20 \text { when } \theta_{c r}=0.04\left(D_{*_{i}}\right)^{-0,1} \\
& 20<D_{*} \leq 150 \text { when } \theta_{c r}=0.013\left(D_{*_{i}}\right)^{-0,29} \\
& D_{*}>150 \text { when } \theta_{c r}=0.055
\end{aligned}
$$

On the basis of the finite solution, the author proposed the following links of determining the comparative cost of ointments:

$$
\begin{aligned}
& \delta_{b}=0.3 d_{a v} D_{*}^{0.7} T^{0.5} \\
& u_{b}=1.5\left[(S-1) g d_{a v}\right]^{0.5} T^{0.6} \\
& C_{b}=0.117 T / D_{*} \\
& q_{b o t}=0.053[(S-1) g]^{0.5} d_{a v}^{1.5} T^{2.1} / D_{*}^{0.3}
\end{aligned}
$$

Van-Rijn Engelund - Hansen's method of calculation, which he created based on the results of Experimental Research [6], Ackers-White [7] and Meyer-Peter-Muller [8] the results of the comparison with the methods are included in Table 1.

As a dimension representing the degree of compatibility of accounting information, the following parameter was adopted:

$$
R=\left(q_{b o t}\right)_{x i s} /\left(q_{b o t}\right)_{x a q}
$$

In Table 1, the following methods with Roman numerals are defined:

I Van-Rijn ; II - Engelund - Hansen ; III - Ackers-White; IV - Meyer-Peter-Muller . 
Table 1.Engelund Van-Rijn method-Hansen [6], Ackers-White [7], Comparison results with the methods of Meyer-Peter-Muller [8]

\begin{tabular}{|c|c|c|c|c|c|c|c|c|c|c|c|c|c|c|c|c|}
\hline \multirow{3}{*}{$\begin{array}{l}\text { Numbe } \\
\text { rof } \\
\text { tests }\end{array}$} & & & & & \multicolumn{4}{|c|}{$0.75 \leq r \leq 1.5$} & \multicolumn{4}{|c|}{$0.5 \leq r \leq 2$} & \multicolumn{4}{|c|}{$0.33 \leq r \leq 3$} \\
\hline & \multicolumn{4}{|c|}{ Changerange } & - & $=$ & $\Xi$ & $\geq$ & - & $=$ & $=$ & $\geq$ & - & $=$ & $=$ & $\geq$ \\
\hline & 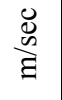 & $\Xi$ & 寻 & ن & \multicolumn{12}{|c|}{$\%$} \\
\hline$\stackrel{\infty}{\infty}$ & సे & $\stackrel{ }{I}$ & 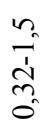 & $\begin{array}{l}\underset{m}{\tilde{b}} \\
\dot{b}\end{array}$ & f & f & $\stackrel{\infty}{+}$ & $\pi$ & 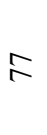 & 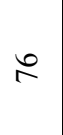 & $\therefore$ & $\stackrel{\infty}{n}$ & 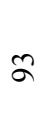 & 8 & 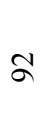 & $\approx$ \\
\hline
\end{tabular}

\section{Method}

The aim of this study was to investigate the movement and size of the underground streams in the channels in the form of the trapezius. The trapezoidal channel is a Van-Rijn [3, 4]. As we have described above in the development of the calculation method of subsurface discharges, has a much more predominant aspect than other calculation methods in our opinion. It was aimed at improving the method of calculation. This method was developed on the basis of the data that the author conducted his experimental research in the stretch, which is very broad. And we use this method on the grunt channels in the form of a trapezium.

To this end, laboratory research was conducted in the laboratory of the counterengineering and economic institute.

In the laboratory, 4 series of experiments were carried out on a trapezoidal channel model with side slopes recovered from the sand (average diameter $d=25 \mathrm{~mm}$ ) inside the metal Lotto. The duration of the experiments was 5-6 hours. At the end of the experiment, we measured the weight $(\mathrm{G})$ of the discharge collected in the sink by washing from the channel model in a weight meter. Also, the cross-sectional profile of the channel was measured. In the process of conducting experiments, such as studies on the washing of the stream $\chi / B$, the movement of underground discharges in the first place was manifested from the places where the channel intersects with the slopes of the bottom and sides. As a result of this, slowly began a violation of the slope $\chi / B$ of the side of the channel and the intensive movement of the axes.

\section{Results and Discussion}

When the experimental laboratory data on the study of tubular discharge are compared with the values calculated according to the Van-Rijn formula, it appears that the data obtained 
under laboratory conditions are slightly larger than the values obtained. The presence of this difference can depend on The Shape of the cut Trapezium, friction on the perimeter of the wetting, the slope of the side of the channel and other factors.

We see that the ratio of the high level of the flow rate of the wetting perimeter to the width affects the depth of the bottom and hanging discharge transport process. Based on this (18), we enter the linkage ratio, and the link takes the following view for trapeziumshaped channels:

$$
q_{b o t}=0.053 \chi / B[(S-1) g]^{0,5} d_{a v}^{1.5} T^{2.1} / D_{*}^{0.3}
$$

In this ratio, $\chi / B$ is the coefficients of slope to the side of the trapezoidal channel are directly involved.

The obtained experiment proved the correctness of the hypothesis that the ratio of the high levels of $\chi / B$ flow rate of the wet perimeter put forward by us when the data is processed statistically affects the process of Subsurface and suspended whitewash transport.

In the conditions of trapezoidal ducts, the link for the full consumption of underground discharges (20) takes the following view:

$$
Q_{b o t}=0.053 \chi[(S-1) g]^{0.5} d_{a v}^{1.5} T^{2.1} / D_{*}^{0.3}
$$

(20) showed much more reliable results than the values calculated according to the formula Van-Rijn, Engelund - Hansen and Ackers-White compared to the values calculated according to the formula(figure 1).

It was also seen that the values calculated by the formula (20) were compared with the values calculated by the Formula Van-Rijn, Engelund - Hansen and Ackers-White.

\section{Concessions}

So, considering the above-mentioned characteristics of underground ores in non-connected ground trapezoidal channels, the recommended connections can be used to predict ores in the channels. 

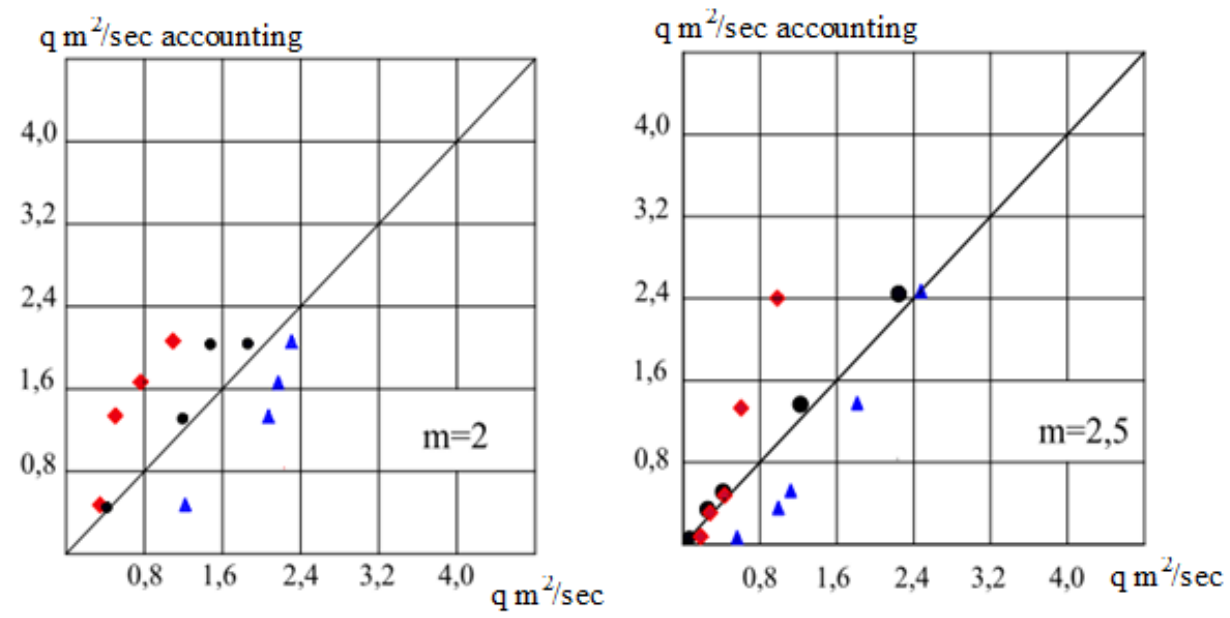

$\mathrm{q} \mathrm{m}^{2} / \mathrm{sec}$ accounting

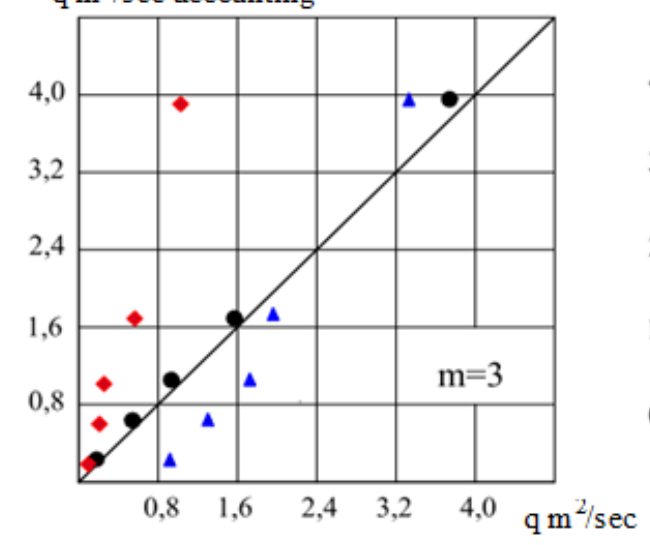

$\mathrm{q} \mathrm{m}^{2} / \mathrm{sec}$ accounting

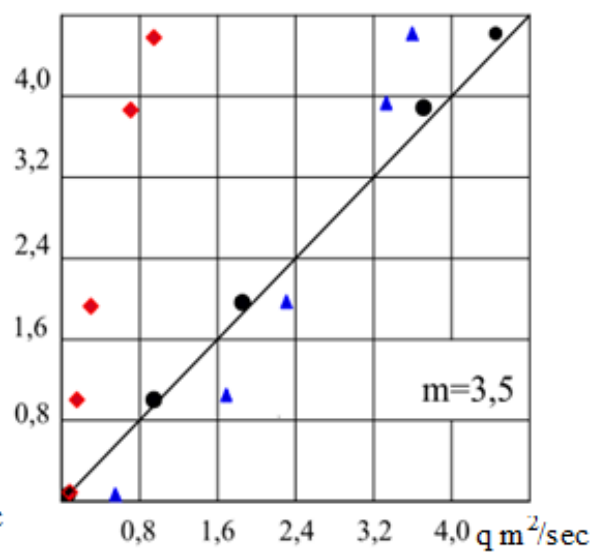

- Van-Rijn

- Ackers-White

$\Delta$ - Engelund- Hansen

Fig. 1.(20) comparison of the values calculated by the formula with the values calculated by the formulas of the following authors: 


\section{References}

1. Eshev S.S. Raschet deformatsiy bol'shikh zemlyanykh kanalov v usloviyakh statsionarnosti vodnogo potoka. Monografiya. Tashkent, «Fan va tekhnologiyalar»,pp.101-108, (2017)

2. Joldassov S.K., Sarbassova G.A., Bekmuratov M.M., Zholamanov N.Z., Yangiev A.A. New structures of sediment exclusion works. News of the National Academy of Sciences of the Republic of Kazakhstan, Series of Geology and Technical Sciences 6(438), pp. 184-189, (2019)

3. Van Rijn L.C. Sediment transport, Part. 1. J. Hydraul. Eng., 110, № 10, p. 1431 1456, (1984)

4. Van-Rayn J.C. Sediment transport. Part. II: Suspended Load Transport. - J. Hudraul Eng. 110, № 11, p. 1613 - 1641, (1984)

5. Schields A. Anwendungde der Ahnlichkeitsmechnic und deirTurbulenzforshungaur die diegeschiebebeweggung. Mitteilungen der Preesseveesuchsanstalt fur wasserbau und schiffbau, Berlin, 26, p. 245, (1936)

6. Engelund R., Hansen E.A. Monograph on sediment transport on Alluvial Streams. Techniques Vorlag Copenhagen, (1967)

7. Ackers P., Ehite W.R. Sediment transport new approach and analysis. Pros ASCE, Now, (HY11-), 99, pp. 2041-2050, (1973)

8. Meyer-Peter E. Miller R. Formulas for bed-load trans ort., Ln. Proc. II Congr. IAHR, Stockhdm, 3, pp. 39-64, (1948)

9. S.Eshev A.Khazratov A Rakhimov Sh.A. Latipov. Influence of wind waves on the flow in flowing reservoirs.IIUM Engineering Journal, 21, № 2, pp.125-132, (2020) doi: https://doi.org/10/31436/iiumej.v21i2.1329.

10. HuanCai-an, ChinTed Yang. Critical unit stream power for sediment transport, J. Hydrodin. 15, № 1, pp. 51-56, (2003)

11. Haiyan Yang, Binliang Lin, Jian Sun and Guoxian Huang, Simulating Laboratory Braided Rivers with Bed-Load Sediment Transport. Water 9, p. 686, (2017)

12. S.Eshev, Sh. Latipov, A.Qurbonov J. Sagdiyev, M. Berdiev, N. Mamatov. Noneroding speed of water flow of channels running in cohesive soils, Intedration, Partnership. Innovationm in construction science-education (IPICSE 2020), IOP Conf. Series: Materials Science and Engineering 1030 (2021), IOP Publishing. doi:10.1088/1757-899X/1030/1/012131

13. Gray A.B., Pasternack G.B., Watson E.B., Warrick J.A., Goni M.A. Effects of antecedent hydrologicconditions, time dependence, and climate cycles on the suspended sediment load of the Salinas River, California. J. Hydrol. 525, pp. 632-649. (2015)

14. Bersi D., Jenkins J.T. A theoretical analysis of free - surface flows of saturated granular liquid mixtures. J.Fluid. Mech. 608, pp. 393-410, (2008)

15. Yangiev A., Salyamova K., Turdikulov K., Fayziev X. Dynamics of an earth dam with account for rheological properties of soil under dynamic effect «IOP Conf. Series: Materials Science and Engineering» 869 (2020)

16. Borovkov V.S. Gidravlika vodnykh i vzvesenesushchikh potokov v zhestkikh i deformiruyemykh granitsakh, p. 260, Moscow, (2009)

17. A Yangiev, S.Eshev, Sh. Panjiev. Calculation of sediment flow in channels taking into account passing and counter wind waves.CONMECHYDRO - 2020 IOP Conf. Series: Materials Science and Engineering .883 (2020) Publishing doi:10.1088/1757899X/883/1/012036. 
18. Mikhalev M.A. Development of the foundations of physical modeling in hydraulics, Izv. VNIIG, 245, pp. 60-68, (2006).

19. S.Eshev, A. Rakhimov, I. Gayimnazarov, A.Isakov, B.Shodiev, F.Bobomurodov. Dynamically stable sections of large soil canals taking into account wind waves. Intedration, Partnership. Innovationm in construction science-education (IPICSE 2020). IOP Conf. Series: Materials Science and Engineering 1030 (2021), doi:10.1088/1757-899X/1030/1/012131

20. Van Rijn, L.C., A simple general expression for longshore transport of sand, gravel and shingle. Coastal Engineering, 90, pp.23-33, (2014)

21. Kosichenko YU.M., Issledovaniye gidravlicheski vygodnogo profilya poligonal'nogo secheniya krupnykh kanalov i ikh gidravlicheskikh soprotivleniy //Priroda ob ustroystvo. № 2. pp.85-89, (2014)

22. Bazarov D., Markova I., Sultanov S. and Kattakulov F. Dynamics of the hydraulic and alluvial regime of the lower reaches of the Amudarya after the commissioning of the Takhiatash and Tuyamuyun hydrosystems. IOP Conf. Ser. Mater. Sci. Eng. 1030, 012110 (2021).

23. Bazarov D., Markova I., Norkulov B. and Vokhidov O. Hydraulic aspects of the layout of head structures during water intake from lowland rivers. IOP Conf. Ser. Mater. Sci. Eng. 1015, 012041 (2021).

24. Bazarov D., Vatin N., Obidov B., and Vokhidov O. Hydrodynamic effects of the flow on the slab of the stand in the presence of cavitation. IOP Conf. Ser. Mater. Sci. Eng. 1030, 012110 (2021).

25. Bazarov D. and Vokhidov O. Extinguishing Excess Flow Energy in Spillway Structures. In book: Proceedings of EECE 2020, LNCE 150, pp. 535-545, (2021) DOI: 10.1007/978-3-030-72404-7_52

26. Obidov B., Vokhidov O., Tadjieva D., Kurbanova, U., Isakov A. Hydrodynamic effects on the flow elements of the downstream devices in the presence of cavitation. IOP Conf. Ser. Mater. Sci. Eng. 1030, 012114 (2021).

27. Krutov A., Choriev R., Norkulov B., Mavlyanova D. and Shomurodov A. Mathematical modelling of bottom deformations in the kinematic wave approximation. IOP Conf. Ser. Mater. Sci. Eng. 1030, 012147 (2021).

28. Krutov A., Norkulov B., Uljaev F., and Jamalov F. Results of a numerical study of currents in the vicinity of a damless water intake. IOP Conf. Ser. Mater. Sci. Eng. 1030, 012121 (2021).

29. Krutov A., Norkulov B., Nurmatov P., Mirzaev M. Applicability of zero-dimensional equations to forecast nonconservative components concentration in water bodies. IOP Conf. Ser. Mater. Sci. Eng. 883(1), 012028 (2020)

30. Shomayramov, M., Norkulov B., Rakhmanov J., Tadjiyeva D., Suyunov J. Experimental researches of hydraulic vacuum breakdown devices of siphon outlets of pumping stations. E3S Web of Conferences, 97, 05009, (2019)

31. Uralov B., Rakhmatov N., Khidirov S., Uljaev F., Raimova I. Hydraulic modes of damless water intake. IOP Conf. Ser. Mater. Sci. Eng. 1030(1), 012123 (2021)

32. Bazarov D., Markova I., Raimova I., Sultanov Sh. Water flow motion in the vehicle of main channels. IOP Conf. Ser. Mater. Sci. Eng. 883, 012025 (2020). 